\title{
Trace-level Lead Analysis in Environmental Water and Whitening Cosmetics Based on Solid-Phase Extraction Followed by Flame Atomic Absorption Spectrometry Determination
}

\author{
Hong-Li Sun, Yi-Wei Wu*, Yang Yu, and Shuai-Hua Zhu \\ Department of Chemistry and Chemical Engineering, \\ Hubei Key Laboratory of Pollutant Analysis and Reuse Technique, Hubei Normal University, \\ Huangshi 435002, P.R. China
}

\section{INTRODUCTION}

Lead is considered one of the most toxic environmental pollutants because of its bioaccumulation and is thus extremely dangerous for all biological organisms, and humans in particular (1). Its effects include not only blood enzyme changes, anaemia, hyperactivity, and neurological disorders, but also pathophysiological changes in several organs $(2,3)$. The World Health Organisation (WHO) recommended a limit of $10 \mu \mathrm{g} \mathrm{L}^{-1}$ as the guideline tolerable value for lead in drinking water (4). In addition, $\mathrm{Pb}$ is also often added to whitening cosmetics owing to its whitening effect. Therefore, highly sensitive determination methods of trace $\mathrm{Pb}$ in environmental samples and whitening cosmetics need to be established.

A separation and preconcentration step is usually necessary prior to the determination of $\mathrm{Pb}$ due to the low levels and the complex matrix. Many preconcentration techniques have been reported, including ion exchange (5), coprecipitation (6), electrodeposition (7), membrane filtration (8), flotation (9), dispersive liquid-liquid microextraction (10), cloud point extraction (11), and solid phase extraction (SPE) $(12,13)$. Among these techniques, SPE has been frequently used for pharmaceutical (14), fine chemicals (15), biological medicine (16), and environmental analysis $(12,13)$ due to its simplic-

* Corresponding author.

E-mail: chemwuyiwei@163.com

\section{ABSTRACT}

Zirconia and alumina doped with silicon material $\left(\mathrm{ZrO}_{2}-\mathrm{Al}_{2} \mathrm{O}_{3}\right.$ $\mathrm{SiO}_{2}$ ) was synthetized by a sol-gel method. A simple and selective method of flow injection (FI) using a micro-column packed with $\mathrm{ZrO}_{2}-\mathrm{Al}_{2} \mathrm{O}_{3}-\mathrm{SiO}_{2}$ as solid phase extractant has been developed for the preconcentration and separation of trace amounts of $\mathrm{Pb}$ in environmental water and whitening cosmetics prior to the determination by flame atomic absorption spectrometry (FAAS). At $\mathrm{pH}$ 4.0-6.0, the doped material was selective towards $\mathrm{Pb}$, and the retained $\mathrm{Pb}$ could be desorbed quantitatively with $4.0 \mathrm{~mL}$ of 0.3 mol L-1 $\mathrm{HCl}$. Under the optimum conditions, the detection limit of $\mathrm{Pb}$ was $1.69 \mathrm{ng} \mathrm{mL}^{-1}$ with an enrichment factor of 50 . The relative standard deviation (RSD) was $1.09 \%\left(\mathrm{n}=9, \mathrm{C}=2 \mathrm{ng} \mathrm{mL}^{-1}\right)$. The proposed method has been successfully applied to the determination of $\mathrm{Pb}$ in environmental water and whitening cosmetics samples, and the recoveries for $\mathrm{Pb}$ were $98.4-109.6 \%$. In order to validate the developed procedure, a GSB-07-1183-2000 certified reference (environmental water) was analyzed, and the results were in good agreement with the certified values.

ity, speed, and ability to provide high enrichment factors.

In the SPE technique, selection of an appropriate sorbent is an important strategy in the elaboration of an analytical procedure, and doped inorganic materials have proved to be especially effective as a result of its high mechanical property, numerous active sites, large surface area, strong adsorption ability, and stability (17). The doped inorganic materials originate in the sol-gel process and usually exhibit specific properties that are not achieved by the individual components (18). Silica-based materials doped with other metallic ions have been widely used in analytical chemistry (19). An SPE-FAAS method using $\mathrm{Fe}_{3} \mathrm{O}_{4}-\mathrm{SiO}_{2}-\mathrm{L}$ as the adsorbent for the determination of $\mathrm{Pb}, \mathrm{Cd}$, and $\mathrm{Cu}$ in water, food, and biological samples has been reported with satisfactory results (20). Farahmand et al. (21) also successfully developed a simple and accurate SPE-FAAS method for the determination of beryllium in aqueous samples using silica gel microparticles doped with alumina as the adsorbent.

The aim of this work is to prepare alumina and zirconia doped with silicon material $\left(\mathrm{ZrO}_{2}-\mathrm{Al}_{2} \mathrm{O}_{3}-\right.$ $\mathrm{SiO}_{2}$ ) by the sol-gel method and explore the possibility of using it as an adsorbent for the extraction of lead prior to its determination by FAAS. Factors affecting $\mathrm{ZrO}_{2}-\mathrm{Al}_{2} \mathrm{O}_{3}-$ $\mathrm{SiO}_{2}$ SPE were investigated in detail. The developed method was applied to the determination of lead in environmental water and whitening cosmetics.

\section{EXPERIMENTAL}

\section{Instrumentation}

The $\mathrm{Pb}$ determination was performed using a Model Shimadzu 6200 atomic absorption spectrome- 
ter (Kyoto, Japan) equipped with deuterium lamp background correction. The operating conditions for $\mathrm{Pb}$ are listed in Table $\mathrm{I}$.

An HL-2 peristaltic pump (Shanghai Qingpu Instrument Factory, P.R. China) and a home-made polytetrafluoroethylene (PTFE) microcolumn (20 mm×3.0 mm i.d.) were used in the extraction process. A minimum length of PTFE tubing $(0.5 \mathrm{~mm}$ i.d.) was used for flow injection (FI).

The reported $\mathrm{pH}$ of the solution was carefully measured with a PHS-3 C pH-meter (Shanghai Precision \& Scientific Instrumental, Shanghai, P.R. China).

Scanning electron micrography (SEM) of $\mathrm{ZrO}_{2}-\mathrm{Al}_{2} \mathrm{O}_{3}-\mathrm{SiO}_{2}$ was performed with a Model S-3400N scanning electron microscope (Hitachi, Tokyo, Japan).

Fourier-transform infrared spectroscopy of $\mathrm{ZrO}_{2}-\mathrm{Al}_{2} \mathrm{O}_{3}-\mathrm{SiO}_{2}$ was performed with a Model 5700 FT-IR (Niconet, USA).

\section{Standard Solution and Reagents}

Stock standard solutions (1 $\mathrm{mg} \mathrm{mL}^{-1}$ ) were prepared by dissolving $\mathrm{Pb}\left(\mathrm{NO}_{3}\right)_{2}$ (Beijing Hengyeyuanzhong Chemical Reagent Corporation, Beijing, P.R. China) in $1 \%(\mathrm{v} / \mathrm{v}) \mathrm{HNO}_{3}$. The standards were further diluted with doubly distilled water (DDW) to prepare working solutions. All reagents were of analytical reagent grade.

For $\mathrm{pH}$ adjustment, a series of Britton-Robison (B-R) buffer solutions were used containing phosphoric acid, acetic acid, and boric acid (Tianjin Kermel Chemical Reagents Development Center, Tianjin, P.R. China), each with concentrations at $0.04 \mathrm{~mol} \mathrm{~L}^{-1}$.

Preparation of $\mathrm{ZrO}_{2}-\mathrm{Al}_{2} \mathrm{O}_{3}-\mathrm{SiO}_{2}$

$\mathrm{ZrO}_{2}-\mathrm{Al}_{2} \mathrm{O}_{3}-\mathrm{SiO}_{2}$ was prepared using Pluronic F127 (EO106PO70 $\mathrm{EO} 106, \mathrm{Mav}=12,600$ ) as template
TABLE I

FAAS Operating Conditions for the Determination of $\mathrm{Pb}$

\begin{tabular}{lr}
\hline Wavelength & $217.0 \mathrm{~nm}$ \\
Lamp Current & $6.0 \mathrm{~mA}$ \\
Spectral Band Pass & $0.7 \mathrm{~nm}$ \\
Burner Height & $8.0 \mathrm{~mm}$ \\
Flow Rate of $\mathrm{C}_{2} \mathrm{H}_{2}$ & $2.0 \mathrm{~mL} \mathrm{~min}$ \\
Flow Rate of Air & $8.0 \mathrm{~mL} \mathrm{m^{-1 }}$ \\
\hline
\end{tabular}

along with $\mathrm{ZrClO} \cdot 8 \mathrm{H}_{2} \mathrm{O}$, tetraethylorthosilicate (TEOS) and $\mathrm{Al}(\mathrm{OiPr})_{3}$ (aluminum isopropoxide) as $\mathrm{Zr}, \mathrm{Si}$, and $\mathrm{Al}$ sources, respectively. The detailed experimental procedure used is similar to reference (22). A quantity of $2.3 \mathrm{~g}$ F127 was dissolved in a mixture of $15 \mathrm{~mL}$ ethanol, $0.1 \mathrm{~mL}$ acetic acid, and $1.0 \mathrm{~mL} \mathrm{35 \%} \mathrm{hydrochloric} \mathrm{acid}$ (HCl). Then, $2.5 \mathrm{mmol} \mathrm{ZrOCl} \cdot 8 \mathrm{H}_{2} \mathrm{O}$ and $5.0 \mathrm{mmol}$ TEOS were sequentially added to the mixed solution with vigorous stirring for 2 hours.

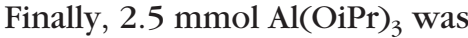
added to the mixture and stirred for another 8 hours at room temperature. The resulting solution was evaporated at 313-323K for 24 hours, and then calcined at $673 \mathrm{~K}$ for 6 hours in order to obtain the doped material of $\mathrm{ZrO}_{2}-\mathrm{Al}_{2} \mathrm{O}_{3}$ $\mathrm{SiO}_{2}$.

\section{SPE Column Preparation}

The PTFE micro-column was filled with a total of $90.0 \mathrm{mg} \mathrm{ZrO}_{2}$ $\mathrm{Al}_{2} \mathrm{O}_{3}-\mathrm{SiO}_{2}$ and both ends were plugged with a small portion of skimmed cotton. The column was conditioned to the desired $\mathrm{pH}$ with B-R buffer solution.

\section{Sample Preparation}

\section{Preparation of Environmental Water Samples}

Environmental water samples (tertiary water treatment from Daye Lake and pond water) were collected and filtered through a $0.45 \mu \mathrm{m}$ membrane (Shanghai Xingyajinghua Instrument Factory, Shanghai, P.R. China). Then the samples were acidified to the proper $\mathrm{pH}$ with B-R buffer prior to their SPE-FAAS analysis.

\section{Preparation of Whitening Cosmetics Samples}

An amount of $5.0 \mathrm{~g}$ whitening cosmetic was dissolved in $50 \mathrm{~mL}$ 1:1 (v/v) $\mathrm{HNO}_{3}$, homogenized, and heated in a boiling water bath for 2 hours. The mixture was then heated $\left(200{ }^{\circ} \mathrm{C}\right)$ in the furnace until the solution was nearly dry. After cooling, the solution was dissolved in $50 \mathrm{~mL}$ B-R buffer prior to SPEFAAS analysis.

\section{General Procedure}

Real-world samples or standard solutions at the proper $\mathrm{pH}$ were passed through the $\mathrm{ZrO}_{2}-\mathrm{Al}_{2} \mathrm{O}_{3}-\mathrm{SiO}_{2}$ micro-column at an optimum flow rate. The analyte trapped in the column was subsequently stripped with the eluent and then determined by FAAS.

\section{RESULTS AND DISCUSSION}

\section{FT-IR Analysis}

To characterize the structural formation of $\mathrm{ZrO}_{2}-\mathrm{Al}_{2} \mathrm{O}_{3}-\mathrm{SiO}_{2}$, Fourier-transform infrared (FTIR) spectroscopy was performed with a Nicolet 5700 FT-IR instrument. As shown in Figure 1, the peaks at 3430 and $1640 \mathrm{~cm}^{-1}$ correspond to the surface adsorbed water molecules and surface - $\mathrm{OH}$ groups, respectively. The absorbance peaks at $1080 \mathrm{~cm}^{-1}, 475 \mathrm{~cm}^{-1}$, and $1390 \mathrm{~cm}^{-1}$ represent the stretching vibration of Si-O-Si, $\mathrm{Zr}-\mathrm{O}-\mathrm{Zr}$, and Al-O bonds, respectively $(23,24)$.

\section{SEM Image Analysis}

The adsorption characteristic of silicon material is related to its physical morphology. Thus, the surface morphology of $\mathrm{ZrO}_{2}-\mathrm{Al}_{2} \mathrm{O}_{3}-\mathrm{SiO}_{2}$ is an important factor affecting its performance. Figure 2 shows the morphology of the $\mathrm{ZrO}_{2}-\mathrm{Al}_{2} \mathrm{O}_{3}-\mathrm{SiO}_{2}$ characterized by SEM at different magnifications. As seen in Figure 2, 
the micrograph of $\mathrm{ZrO}_{2}-\mathrm{Al}_{2} \mathrm{O}_{3}-\mathrm{SiO}_{2}$ displays a roughened and porous structure.

\section{Effect of $\mathbf{p H}$}

The $\mathrm{pH}$ value plays an important role in the adsorption of different ions on $\mathrm{ZrO}_{2}-\mathrm{Al}_{2} \mathrm{O}_{3}-\mathrm{SiO}_{2}$. To characterize the selectivity of $\mathrm{ZrO}_{2}-\mathrm{Al}_{2} \mathrm{O}_{3}$ $\mathrm{SiO}_{2}$, a number of metal ions (Cr, $\mathrm{Cu}, \mathrm{Cd}$, and $\mathrm{Pb}$ ) were tested at varying $\mathrm{pH}$, and the experimental results are shown in Figure 3. As seen, $\mathrm{Pb}$ can be quantitatively adsorbed while $\mathrm{Cr}, \mathrm{Cu}$, and $\mathrm{Cd}$ cannot. A quantitative adsorptive rate (>90\%) was found for $\mathrm{Pb}$ in the $\mathrm{pH}$ range of 4.5-6.0. As a result, $\mathrm{ZrO}_{2}$ $\mathrm{Al}_{2} \mathrm{O}_{3}-\mathrm{SiO}_{2}$ exhibited good selectivity towards $\mathrm{Pb}$, and the $\mathrm{pH}$ of 4.5 was selected for the preconcentration and separation of $\mathrm{Pb}$.

\section{Effect of Sample Flow Rate}

The retention of an analyte on the adsorbent depends on the flow rate of the sample solution. In order to improve the analysis efficiency, it was examined under the optimal $\mathrm{pH}$ with flow rates varying from 0.2

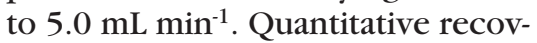
eries of $\mathrm{Pb}$ were obtained at flow rates of less than $4.0 \mathrm{~mL} \mathrm{~min}^{-1}$. Thus, a flow rate of $4.0 \mathrm{~mL} \mathrm{~min}^{-1}$ was employed as the optimum.

\section{Effect of Elution Conditions}

With respect to stripping $\mathrm{Pb}$ from $\mathrm{ZrO}_{2}-\mathrm{Al}_{2} \mathrm{O}_{3}-\mathrm{SiO}_{2}$, a series of concentrations $\left(0.1-2.0 \mathrm{~mol} \mathrm{~L}^{-1}\right)$ of $\mathrm{HCl}$ were studied. The results in Figure 4 show that $\mathrm{Pb}$ was completely desorbed quantitatively (> 90\%) with 0.1-2.0 $\mathrm{mol} \mathrm{L}^{-1} \mathrm{HCl}$. Thus, $0.3 \mathrm{~mol} \mathrm{~L}^{-1} \mathrm{HCl}$ was selected to strip the analyte.

To obtain a significant enrichment factor, the volume of the eluent should be as small as possible. By keeping the $\mathrm{HCl}$ concentration at $0.3 \mathrm{~mol} \mathrm{~L}^{-1}$, the effect of eluent volume on the recoveries of $\mathrm{Pb}$ was investigated. The results showed that $4.0 \mathrm{~mL}$ of $0.3 \mathrm{~mol} \mathrm{~L}^{-1} \mathrm{HCl}$ was sufficient to quantitatively recover $\mathrm{Pb}$.

The effect of the desorption flow rate of $0.3 \mathrm{~mol} \mathrm{~L}^{-1} \mathrm{HCl}$ was

\section{Atomic Apectroscopy \\ 1 Vol. 35(3), May/June 2014}

further studied at a range of $0.2-2.5 \mathrm{~mL} \mathrm{~min}^{-1}$ fixing the eluent volume at $4.0 \mathrm{~mL}$. The results in Figure 5 show that the recoveries of $\mathrm{Pb}$ strongly depend on the eluent flow rate. The higher the flow rate of $\mathrm{HCl}$, the lower the recovery of $\mathrm{Pb}$. When the flow rate was less than $1.5 \mathrm{~mL} \mathrm{~min}^{-1}$, the recoveries of $\mathrm{Pb}$ were over $90 \%$. Thus, $1.0 \mathrm{~mL}$ $\mathrm{min}^{-1}$ was selected as the optimum.

\section{Effect of Sample Volume}

To explore the possibility of enriching low concentrations of the analyte from a large volume, the effect of sample volume on the $\mathrm{Pb}$ recovery was investigated. For this purpose, $10.0-250.0 \mathrm{~mL}$ of sample solutions containing $5.0 \mu \mathrm{g} \mathrm{mL}^{-1} \mathrm{~Pb}$ were passed through the microcolumn at the optimum conditions. Up to a sample volume of $200.0 \mathrm{~mL}$.

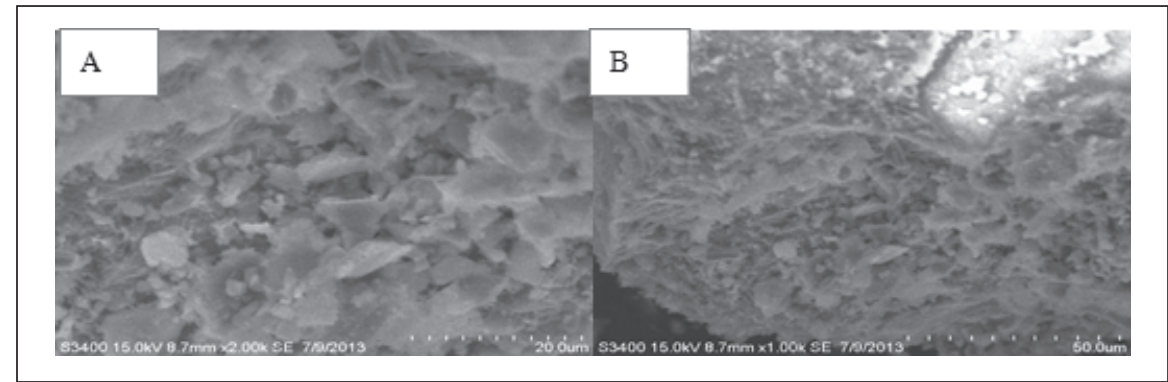

Fig. 2. SEM image of $\mathrm{ZrO}_{2}-\mathrm{Al}_{2} \mathrm{O}_{3}-\mathrm{SiO}_{2}$ at (A) $2000 \times$ and (B) $1000 \times$ magnification.

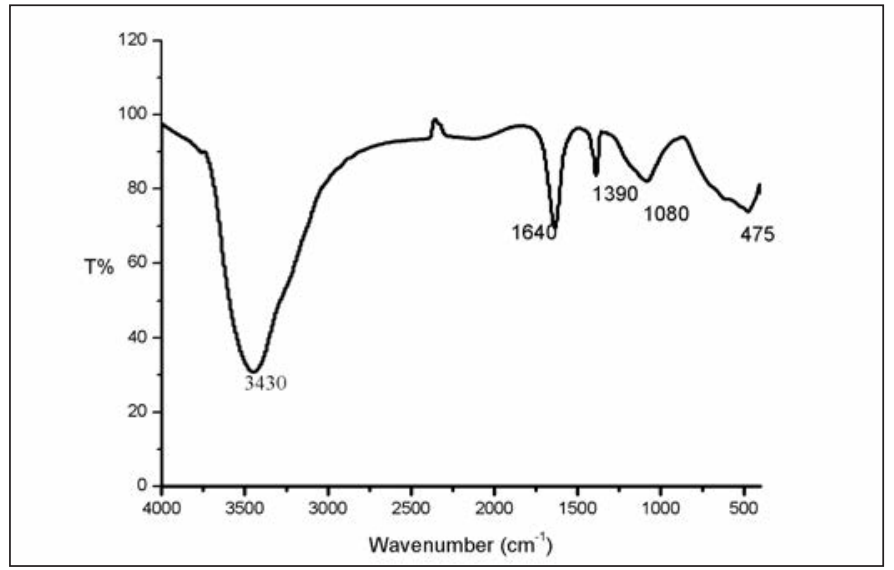

Fig. 1. FT-IR spectra of $\mathrm{ZrO}_{2}-\mathrm{Al}_{2} \mathrm{O}_{3}-\mathrm{SiO}_{2}$.

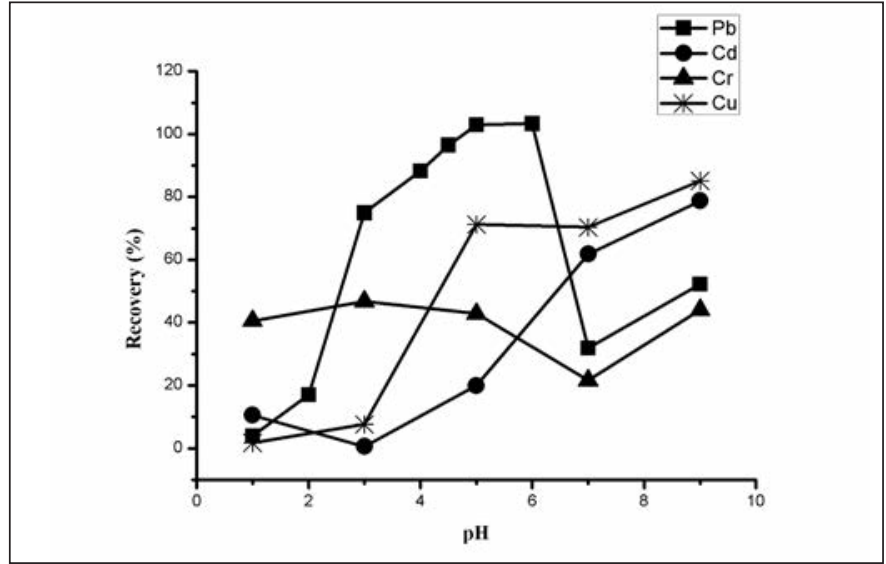

Fig. 3. Effect of $\mathrm{pH}$ on the adsorption of $5.0 \mu \mathrm{g} \mathrm{mL}^{-1} \mathrm{~Pb}, 2.0 \mu \mathrm{g}$ $m L^{-1} \mathrm{Cd}$, $2.0 \mu \mathrm{g} \mathrm{mL}^{-1} \mathrm{Cr}$ and $1.0 \mu \mathrm{g} \mathrm{mL}^{-1} \mathrm{Cu}$ on $\mathrm{ZrO}_{2}-\mathrm{Al}_{2} \mathrm{O}_{3}-\mathrm{SiO}_{2}$. 
quantitative recovery (>90\%) was obtained. As described previously, $4.0 \mathrm{~mL}$ of $0.3 \mathrm{~mol} \mathrm{~L}^{-1} \mathrm{HCl}$ was sufficient to elute the analyte retained on $\mathrm{ZrO}_{2}-\mathrm{Al}_{2} \mathrm{O}_{3}-\mathrm{SiO}_{2}$. An enrichment factor of 50 was achieved for $\mathrm{Pb}$ by this method. In our procedure, sample volumes of $200 \mathrm{~mL}$ and $50 \mathrm{~mL}$ were ultimately chosen for environmental water and the whitening cosmetic, respectively.

\section{Adsorptive Capacity}

The adsorptive capacity is an important factor to evaluate the adsorption performance of $\mathrm{ZrO}_{2}-$ $\mathrm{Al}_{2} \mathrm{O}_{3}-\mathrm{SiO}_{2}$, because it determines how much $\mathrm{ZrO}_{2}-\mathrm{Al}_{2} \mathrm{O}_{3}-\mathrm{SiO}_{2}$ is required to quantitatively concentrate $\mathrm{Pb}$ from a given solution.

\section{Static Adsorptive Capacity}

Using a $\mathrm{pH} 4.5$ and a 10-minute stirring time as the adsorptive conditions, a $20-\mathrm{mg}$ portion of $\mathrm{ZrO}_{2}-$ $\mathrm{Al}_{2} \mathrm{O}_{3}-\mathrm{SiO}_{2}$ was shaken with $100 \mathrm{~mL}$ aqueous solution containing 0.1-10.0 $\mu \mathrm{g} \mathrm{mL} \mathrm{m}^{-1}$ of $\mathrm{Pb}$. After the distribution equilibrium was reached, the concentration of $\mathrm{Pb}$ in solution was determined. The results showed that the static adsorptive capacity of the doped material for $\mathrm{Pb}$ was $15.0 \mathrm{mg} \mathrm{g}^{-1}$.

\section{Dynamic Adsorptive Capacity}

Under optimum conditions, the determination of the dynamic adsorptive capacity of $\mathrm{Pb}$ was performed, and $100 \mathrm{~mL}$ of a series of $\mathrm{Pb}$ concentrations $\left(0.1-10.0 \mu \mathrm{g} \mathrm{mL} \mathrm{m}^{-1}\right)$ was investigated. The results showed that the micro-column was saturated at $100 \mathrm{~mL}$ of $10.0 \mu \mathrm{g} \mathrm{mL}^{-1}$ of $\mathrm{Pb}$, and the dynamic adsorption capacity of $\mathrm{ZrO}_{2}-\mathrm{Al}_{2} \mathrm{O}_{3}-\mathrm{SiO}_{2}$ for $\mathrm{Pb}$ was $11.1 \mathrm{mg} \mathrm{g}^{-1}$.

\section{Interferences}

The effects of common coexisting cations and anions as commonly expected in environmental water or whitening cosmetics on $\mathrm{Pb}$ extraction by $\mathrm{ZrO}_{2}-\mathrm{Al}_{2} \mathrm{O}_{3}-\mathrm{SiO}_{2}$ were examined. Solutions of $5.0 \mu \mathrm{g} \mathrm{mL}^{-1}$ $\mathrm{Pb}$ containing the added interfering ions were treated according to the recommended procedure. The results are listed in Table II. The effect expresses the recovery in the presence of interfering ions relative to the interference-free response. As seen, $5.0 \mathrm{mg} \mathrm{mL}^{-1} \mathrm{Na}^{+}, 10.0 \mathrm{mg}$ $\mathrm{mL}^{-1} \mathrm{~K}^{+}, 15.0 \mathrm{mg} \mathrm{mL}^{-1} \mathrm{Ca}^{2+}, \mathrm{Mg}^{2+}$, $1.0 \mathrm{mg} \mathrm{mL}^{-1} \mathrm{Al}^{3+}, 9.2 \mathrm{mg} \mathrm{mL}^{-1} \mathrm{Cl}^{-}$, $10.4 \mathrm{mg} \mathrm{mL}^{-1} \mathrm{SO}_{4}^{2-}$, and $6.89 \mathrm{mg}^{-}$ $\mathrm{mL}^{-1} \mathrm{NO}_{3}^{-}$have no obvious influence on the separation or determination of $\mathrm{Pb}$ under the selected conditions.

\section{Regeneration and Stability of $\mathrm{ZrO}_{2}-\mathrm{Al}_{2} \mathrm{O}_{3}-\mathrm{SiO}_{2}$}

To test the stability and potential regeneration of the adsorbent, it must be subjected to successive adsorption and elution cycles at optimum conditions. The results

TABLE II

Effects of Interfering Ions on Determining of $5.0 \mu \mathrm{g} \mathrm{mL}^{-1} \mathrm{~Pb}$

\begin{tabular}{|c|c|c|c|c|c|c|c|c|}
\hline Interfering Ions & $\mathrm{K}^{+}$ & $\mathrm{Na}^{+}$ & $\mathrm{Ca}^{2+}$ & $\mathrm{Mg}^{2+}$ & $\mathrm{Al}^{3+}$ & $\mathrm{Cl}^{-}$ & $\mathrm{SO}_{4}{ }^{2-}$ & $\mathrm{NO}_{3}{ }^{-}$ \\
\hline Permit ratio $^{a}$ & 2000 & 1000 & 3000 & 3000 & 200 & 1846 & 2087 & 1378 \\
\hline Recovery $^{\mathrm{b}}(\%)$ & 90.50 & 90.37 & 93.55 & 94.33 & 90.11 & 90.50 & 90.37 & 90.11 \\
\hline
\end{tabular}

${ }^{a}$ Concentration ratio of the interfering ions to the analyte.

${ }^{\mathrm{b}}$ Recovery of the analyte.

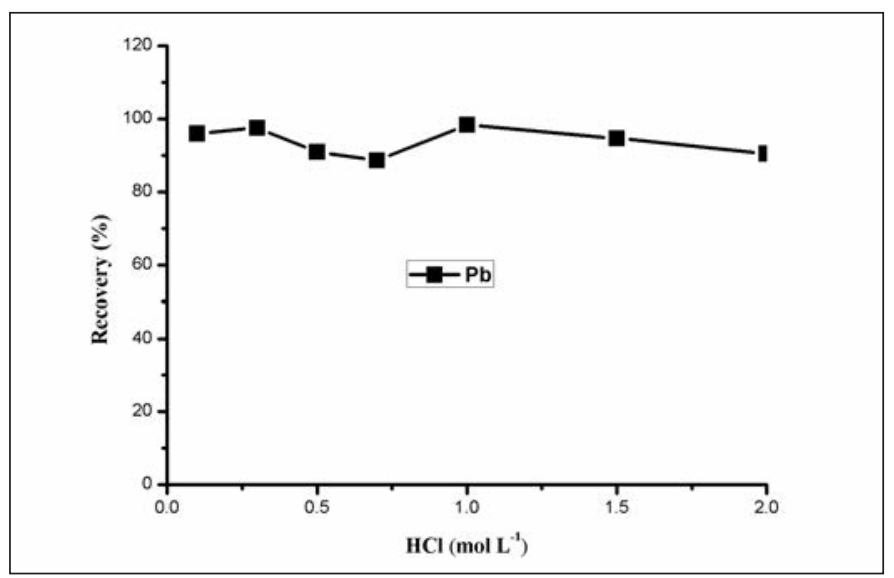

Fig. 4. Effect of HCl concentration on the desorption of $\mathrm{Pb}$ on $\mathrm{ZrO}_{2}-\mathrm{Al}_{2} \mathrm{O}_{3}-\mathrm{SiO}_{2}$

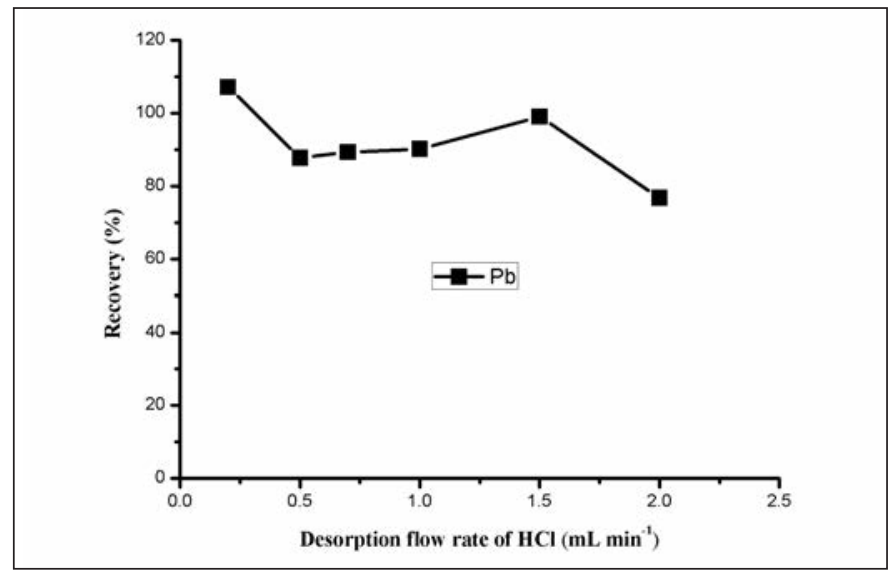

Fig. 5. Effect of desorption flow rate of $\mathrm{HCl}$ on the recoveries of $\mathrm{Pb}$ on $\mathrm{ZrO}_{2}-\mathrm{Al}_{2} \mathrm{O}_{3}-\mathrm{SiO}_{2}$. 
showed that $\mathrm{ZrO}_{2}-\mathrm{Al}_{2} \mathrm{O}_{3}-\mathrm{SiO}_{2}$ can be re-used after regeneration with $10 \mathrm{~mL}$ of distilled water and is stable for up to 10 times adsorptionelution cycles without obvious decrease in the recoveries of $\mathrm{Pb}$.

\section{Analytical Performance}

Under the optimized experimental conditions, the detection limit (LOD, calculated as the concentration corresponding to three times the standard deviation of 9 runs of the blank samples) of the method for $\mathrm{Pb}$ with an enrichment factor of 50 was $1.69 \mathrm{ng} \mathrm{mL}^{-1}$, and the relative standard deviation (RSD) was $1.09 \%\left(\mathrm{n}=9, \mathrm{C}=2 \mathrm{ng} \mathrm{mL}^{-1}\right)$. A com- parison of the proposed method to some recent papers on $\mathrm{Pb}$ determination by SPE is given in Table III. As seen, the obtained LOD is lower than in the studies by Ungoren et al. (27) and Ghaedi et al. (20), and close to the reports by Al-qadami et al. (2) and Wang et al. (28).

\section{Analytical Application}

The proposed method was applied to the determination of $\mathrm{Pb}$ in pond water, tertiary treatment water from Daye Lake, and whitening cosmetic samples. The realworld samples and their spiked recoveries were treated as in the Sample Preparation section. The

\section{Atomic Mpectroscopy \\ $\bigcup$ Vol. 35(3), May/June 2014}

analytical results, listed in Tables IV and $\mathrm{V}$, show that the recoveries of $\mathrm{Pb}$ were 98.4-109.6\%, indicating that the proposed method is suitable and acceptable.

In order to establish the validity of the proposed procedure, the method was applied to the determination of $\mathrm{Pb}$ in certified reference material GSB 07-1183-2000 Environmental Water (Beijing Haotian Wing Tai Technology Co., Ltd., P.R. China). The content of $\mathrm{Pb}$ was determined according to the recommended procedure. The analytical result $(0.384 \pm 0.017)$ showed that it was in good agreement with the certified value $(0.378 \pm 0.017)$.

TABLE III Comparison of Proposed Method with Earlier Reported Methods

\begin{tabular}{|c|c|c|c|c|c|c|}
\hline Matrix & Analytes & Extraction Solvents & Technique & LODs & $\mathrm{EF}^{\mathrm{a}}$ & Ref. \\
\hline $\begin{array}{l}\text { Rice Flour and } \\
\text { Tea }\end{array}$ & $\mathrm{Pb}(\mathrm{II})$ & $\begin{array}{l}\text { Halloysite nanotubes } \\
\text {-N-2-Pyridylsuccinamic acid }\end{array}$ & ICP-OES & $0.32 \mathrm{ng} \mathrm{mL}^{-1}$ & 67 & (25) \\
\hline Milk and Yogurt & $\begin{array}{l}\mathrm{Pb}(\mathrm{II}) \\
\text { and } \mathrm{Ni}(\mathrm{II})\end{array}$ & $\begin{array}{l}\text { Aminothioazole-containing } \\
\text { sulfonamide resin }\end{array}$ & FAAS & $\begin{array}{l}0.15(\mathrm{~Pb}) \text { and } \\
0.75(\mathrm{Ni}) \mathrm{ng} \mathrm{mL} \mathrm{mL}^{-1}\end{array}$ & $\begin{array}{l}\mathrm{Pb} 350 \\
\mathrm{Ni} 50\end{array}$ & (26) \\
\hline Seawater & $\begin{array}{l}\mathrm{Mn}(\mathrm{II}), \mathrm{Co}(\mathrm{II}), \\
\mathrm{Ni}(\mathrm{II}), \mathrm{Zn}(\mathrm{II}), \\
\text { and } \mathrm{Pb}(\mathrm{II})\end{array}$ & $\begin{array}{l}\text { 2,4-Dioxobutyl-chelating } \\
\text { resin }\end{array}$ & FAAS & $\begin{array}{l}3.8(\mathrm{Co}), 3.7(\mathrm{Mn}) \\
1.8(\mathrm{Ni}), 6.1(\mathrm{~Pb}) \\
0.5(\mathrm{Zn}) \mathrm{ng} \mathrm{mL}^{-1}\end{array}$ & $\begin{array}{l}\text { Co } 50 \\
\text { Mn } 50 \\
\text { Ni } 100 \\
\text { Pb } 100 \\
\text { Zn } 100\end{array}$ & $(27)$ \\
\hline $\begin{array}{l}\text { Whitening } \\
\text { Cosmetics }\end{array}$ & $\begin{array}{l}\text { As, } \mathrm{Bi}, \mathrm{Cd}, \mathrm{Pb} \text {, } \\
\mathrm{Hg} \text { and } \mathrm{Ti}\end{array}$ & $\begin{array}{l}\text { Multiwalled carbon } \\
\text { nanotubes }\end{array}$ & ICP-AES & $\begin{array}{l}2.4(\mathrm{As}), 4.08(\mathrm{Bi}) \\
0.3(\mathrm{Cd}), 2.1(\mathrm{~Pb}) \\
1.8(\mathrm{Hg}) \text { and } \\
1.8(\mathrm{Ti}) \mathrm{ng} \mathrm{mL}^{-1}\end{array}$ & & (2) \\
\hline $\begin{array}{l}\text { Water, Food and } \\
\text { Biological samples }\end{array}$ & $\begin{array}{l}\mathrm{Pb}(\mathrm{II}), \mathrm{Cd}(\mathrm{II}) \\
\text { and } \mathrm{Cu}(\mathrm{II})\end{array}$ & $\mathrm{Fe}_{3} \mathrm{O}_{4} / \mathrm{SiO}_{2} / \mathrm{L}$ & FAAS & $\begin{array}{l}0.14(\mathrm{~Pb}), 0.19(\mathrm{Cd}) \text {, } \\
\text { and } 0.12(\mathrm{Cu}) \mathrm{ng} \mathrm{mL}^{-1}\end{array}$ & 87 & (20) \\
\hline Environmental Water & $\mathrm{Pb}(\mathrm{II})$ & Carbon nanostructures, & FAAS & $0.61 \mathrm{ng} \mathrm{mL}^{-1}$ & 125 & $(28)$ \\
\hline Tap and Wastewater & $\mathrm{Pb}(\mathrm{II})$ & Ground eucalyptus stem & FAAS & $4.5 \mathrm{ng} \mathrm{mL}^{-1}$ & 50 & $(29)$ \\
\hline Fruit and Leaves & $\begin{array}{l}\mathrm{Fe}(\mathrm{III}), \mathrm{Pb}(\mathrm{II}), \\
\mathrm{Ni}(\mathrm{II}) \text { and } \\
\mathrm{Zn}(\mathrm{II})\end{array}$ & $\begin{array}{l}\text { Sodium dodecyl sulfate } \\
\text { (SDS)-coated alumina }\end{array}$ & FAAS & $\begin{array}{l}1.6(\mathrm{Zn}), 2.6(\mathrm{Fe}) \\
2.8(\mathrm{~Pb}) \text { and } \\
2.1(\mathrm{Ni}) \mathrm{ng} \mathrm{mL}^{-1}\end{array}$ & 63 & (30) \\
\hline Water and Food & $\begin{array}{l}\mathrm{Cu}(\mathrm{II}), \mathrm{Cd}(\mathrm{II}) \\
\mathrm{Pb}(\mathrm{II}) \text { and } \mathrm{Ni} \text { (II) }\end{array}$ & Sepabeads SP-207 resin & FAAS & $\begin{array}{l}0.18(\mathrm{Cu}), 0.17(\mathrm{Cd}) \\
0.55(\mathrm{~Pb}) \text { and } \\
1.67(\mathrm{Ni}) \mathrm{ng} \mathrm{mL}^{-1}\end{array}$ & 50 & (31) \\
\hline Water and Whitening & $\mathrm{Pb}(\mathrm{II})$ & $\mathrm{ZrO}_{2} / \mathrm{Al}_{2} \mathrm{O}_{3} / \mathrm{SiO}_{2}$ & FAAS & $1.69 \mathrm{ng} \mathrm{mL}^{-1}$ & 50 & $\begin{array}{l}\text { This } \\
\text { work }\end{array}$ \\
\hline
\end{tabular}

\footnotetext{
${ }^{a}$ Enrichment Factor.
} 


\section{CONCLUSION}

$\mathrm{ZrO}_{2}-\mathrm{Al}_{2} \mathrm{O}_{3}-\mathrm{SiO}_{2}$ silicon material was prepared simply by the sol-gel method, and its adsorptive performance for metallic ions was investigated. $\mathrm{ZrO}_{2}-\mathrm{Al}_{2} \mathrm{O}_{3}-\mathrm{SiO}_{2}$ microcolumn extraction, resulting in a 50-fold enrichment factor, was utilized for improving the selectivity and sensitivity of FAAS in the determination of $\mathrm{Pb}$. A simple, selective, and sensitive method was therefore developed for the determination of $\mathrm{Pb}$ in environmental water and whitening cosmetics samples by using $\mathrm{ZrO}_{2}-\mathrm{Al}_{2} \mathrm{O}_{3}-\mathrm{SiO}_{2}$ as the extraction adsorbent. In comparison to some of the previously published works on the same subject, the obtained LOD was lower than that of some other works.

\section{ACKNOWLEDGMENTS}

This project was financially supported by the National Nature Science Foundation of China (No. 20975031, 21075030), Education Committee of Hubei Province (D20132501), Hubei Key Laboratory of Pollutant Analysis and Reuse Technique (Hubei Normal University) (KL2013M06), Young and Middle-Aged Elitists' Scientific and the Technological Innovation Team Project of Hubei Education Department of China under Grant (T201007).

Received November 23, 2013.
TABLE IV

Analytical Results of $\mathrm{Pb}$ in Environmental Water by $\mathrm{ZrO}_{2}-\mathrm{Al}_{2} \mathrm{O}_{3}-\mathrm{SiO}_{2}$ Micro-Column SPE-FAAS

\begin{tabular}{lccc}
\hline \multicolumn{1}{c}{ Samples } & $\begin{array}{c}\text { Added } \\
\left(\mu \mathrm{g} \mathrm{mL}^{-1}\right)\end{array}$ & $\begin{array}{c}\text { Found }^{\mathrm{a}} \\
\left(\mu \mathrm{g} \mathrm{mL}^{-1}\right)\end{array}$ & $\begin{array}{c}\text { Recovery } \\
(\%)\end{array}$ \\
\hline $\begin{array}{l}\text { Tertiary Water } \\
\text { Treatment from Daye }\end{array}$ & 0 & $\mathrm{ND}^{\mathrm{b}}$ & - \\
& 1 & $1.096 \pm 0.018$ & 109.6 \\
& 5 & $5.11 \pm 0.00032$ & 102.2 \\
Pond Water & 0 & $0.27 \pm 0.018$ & - \\
& 1 & $1.249 \pm 0.011$ & 98.5 \\
& 5 & $5.185 \pm 0.012$ & 98.4
\end{tabular}

\footnotetext{
${ }^{\mathrm{a}}$ For three parallel samples.

b Not detected.
}

TABLE V

Analytical Results of $\mathrm{Pb}$ in Whitening Cosmetics by $\mathrm{ZrO}_{2}-\mathrm{Al}_{2} \mathrm{O}_{3}-\mathrm{SiO}_{2}$ Micro-column SPE-FAAS

\begin{tabular}{cccc}
\hline Samples & $\begin{array}{c}\text { Added } \\
\left(\mu \mathrm{g} \mathrm{mL}^{-1}\right)\end{array}$ & $\begin{array}{c}\text { Found }^{\mathrm{a}} \\
\left(\mu \mathrm{g} \mathrm{mL}^{-1}\right)\end{array}$ & $\begin{array}{c}\text { Recovery } \\
(\%)\end{array}$ \\
\hline Sample 1 & 0 & $0.3001 \pm 0.035$ & - \\
Sample 2 & 1 & $1.296 \pm 0.018$ & 99.6 \\
& 5 & $5.3063 \pm 0.0044$ & 100.1 \\
& 0 & $\mathrm{ND}^{\mathrm{b}}$ & - \\
& 1 & $0.9941 \pm 0.0099$ & 99.7 \\
\hline
\end{tabular}

${ }^{a}$ For three parallel samples.

b Not detected.

Samples 1 and 2: Whitening cosmetics (from different companies). 


\section{Atomic $_{\text {Spectroscopy }}^{\text {to }}$ \\ 1 Vol. 35(3), May/June 2014}

\section{REFERENCES}

1. A.M.L. Marzo, J. Pons, D. A. Blake and A. Merkoc, Biosens Bioelectron 47, 190 (2013).

2. A.A. ALqadami, M. A. Abdalla, Z. A. ALOthman and Kamal Omer, Int. J. Environ. Res. Public Health 10, 361 (2013).

3. X.S. Wei, A. M. Yu, M. X. Han, J. Zhang, H. L. Zhang and Y. W. Wu, At. Spectrosc. 33, 67 (2012).

4. World Health Organization, Health Criteria and Other Supporting Information (1996).

5. P. N. Nomngongo, J. C. Ngila, J. N. Kamau, T. A.M. Msagati, L. Marjanovic and B. Moodley, Anal. Chim. Acta 787, 78 (2013).

6. J. X. Qiao, X. L. Hou and P. Roos, Anal. Chem. 85, 1889 (2013).

7. R. Moradkhani, A. Rouhollahi, H. Shirkhanloob and J. B. Ghasemia, J. Chin. Chem. Soc. 60, 481 (2013).

8. C. H. Yin, J. Iqbal, H. L. Hu, B. X. Liu, L. Zhang, B. L. Zhu and Y. P. Du, J. Hazard Mater. 233, 207 (2013).

9. M. Shamsipur, R. Davarkhah, R. Hassani and A. R. Khanchi, Sep. Sci. Technol. 45, 1340 (2010).

10. I. L. Garc, Y. V. Martinez and M. H. Cordoba, Talanta 110, 46 (2013).

11. J. B. Burnecka, A. S. Madej and W. Zyrnicki, J. Hazard Mater. 182, 477 (2010).

12. Y. Date, A. Aota, S. Terakado, K. Sasaki, N. Matsumoto, Y. Watanabe, T. Matsue and $\mathrm{N}$. Ohmura, Anal. Chem. 85, 434 (2013).

13. Y. B. Zhu and K. Chiba, Talanta 90 , 57 (2012)

14. N. Gilart, R. M. Marcé, N. Fontanals and F. Borrull, Talanta 110, 196 (2013).

15. M.C. P. Blancoa, Y. M. Martinez and P. C. Falcób, J. Chromatogr. A 1297, 226 (2013).
16. M. Shekarchia, M. Pourfarzib, B. A. Adergania, A. Mehramizic, M. Javanbakhtd and R. Dinarvand, J. Chromatogr. B 931, 50 (2013).

17. M. M. Rahman, S. B. Khan, H. M. Marwani, A. M. Asiri and K. A. Alamry, Chem. Cent. J. 6, 158 (2012).

18. K. Shiba1, M. Tagaya, R. D. Tilley and N. Hanagata, Sci. Technol. Adv. Mater. 14, 1 (2013).

19. H.G. Lin, T. Gan and K. B. Wu, Food Chem. 113, 701 (2009).

20. H. Bagheri, A. Afkhami, M. S. Tehrani and $\mathrm{H}$. Khoshsafar, Talanta 97, 87 (2012).

21. A. R. Farahmand, S. R. Yousefi, N. S. Fumani, S. Mirza, M. Shamsipur and J. Hassan, Microchim. Acta 166,89 (2009).

22. N. Pal, M. M. Seikh and A. Bhaumik, J. Solid State Chem. 198, 114 (2013).

23. L. Sowntharya, R. C. Gundakaram, K.R.C. SomaRaju and R. Subasri, Ceram. Int., 39, 4245 (2013).

24. G. Y. Fang, H. Li, L. Cao and F. Shan, Mater. Chem. Phys., 137, 558 (2012).

25. Q. He, D. Yang, X. L. Deng, Q. Wu, R. J. Li, Y. H. Zhai and L. J. Zhang, Water Research 47, 3976 (2013).

26. C. Er, B. F. Senkal and M. Yaman, Food Chem. 137, 55 (2013).

27. S. H. Ungoren and S. Kartal, J. Appl. Polym. Sci. 2414 (2013).

28. Y. K. Wang, S. T. Gao, X. H. Zang, J. C. Li and J. J. Ma, Anal Chim. Acta 716, 112 (2012)

29. H. Z. Mousavi, B. A. Esfahani and A. Arjmandi, J. Chin. Chem. Soc-Taip 56, 974 (2009).

30. M. Ghaedi, H. Tavallali, A. Shokrollahi, M. Zahedi, M. Montazerozohoria and M. Soylakc, J. Hazard Mater. 166, 1441 (2009)

31. D. Mendil, T. Kiris, M. Tuzen and Mustafa Soylak, Int. J. Food Sci. Tech. 48, 1201 (2013). 